\title{
Introduction: Time and the Cosmos in Plato and the Platonic Tradition
}

\author{
Daniel Vázquez
}

Time and cosmology are strongly interconnected in the Platonic corpus. The way Plato's characters discuss these topics has puzzled and divided readers from the very beginning, giving rise to rich and diverse interpretations. Do Plato's dialogues argue for an eternal cosmos or one with a punctual beginning? What is the nature of time, and how should we understand its relation to eternity, change, and transition? How should we understand the relation between God, the cosmos, and time? The present volume assembles an international team of ancient philosophy scholars to engage with Plato's texts, and their ancient and modern interpretations, and to answer these and other closely related questions. The overall purpose of the volume is to push forward the study and understanding of Plato's conception of time and the cosmos as a way of finding fresh insight into the interpretation of his philosophy and his reception in antiquity. I begin with an introduction to these topics in Plato and the Platonic tradition broadly understood, before explaining the motivation and overall structure of the volume. I conclude by offering a concise description of the contents of each chapter.

\section{Plato on Time and the Cosmos}

Timaeus is the dialogue that examines more explicitly the interconnection between time and the cosmos in the Platonic corpus. There, Plato's character Timaeus ${ }^{1}$ offers a detailed speech about the creation of the world and everything in it, including the stars, the earth, all living creatures, and, crucially, time. Timaeus credits the creation of all these things to a divine craftsman, ${ }^{2}$ a benevolent and intelligent God who creates by imitating an unchanging and

1 Plato describes Timaeus as a rich, well-born expert in astronomy who has held high political offices in his natal Locri. There is no other record of him outside the Timaeus and Critias, which suggests that he is a Platonic invention. See Nails $(1998,293)$.

2 Timaeus calls him a "demiurge" dèmiurgos (Ti. 28a6), a "maker" poiētēs (Ti. 28c3), a "father" patèr (Ti. 28c3) and an "artificer" ho tektainomenos (Ti. 28c6). 
eternal model, introducing order to a pre-existing chaos made from traces of earth, water, fire, and air.

The speech has a complex and multi-layered structure. The dramatic setting is a meeting between Socrates, Hermocrates, Critias, and Timaeus on the occasion of the Panathenaea festival. ${ }^{3}$ At the beginning of the dialogue, we learn that Socrates made a speech the day before, and now it is the turn of his interlocutors to reciprocate his efforts. ${ }^{4}$ Timaeus, who knows about astronomy and natural science (Timaeus 27a3-6), gives the first speech of this sequence, and his task is to start with the origin of the universe and end with the nature of human beings (Timaeus 27 a5-6). ${ }^{5}$

Timaeus begins with an invocation for the approval of the gods, goddesses, and their interlocutors (Timaeus 27c). Then, he offers a preamble to clarify his starting point and general principles (Timaeus $27 \mathrm{~d}-29 \mathrm{~d}$ ). This includes the distinction between "that which always is and has no becoming" (Timaeus $27 \mathrm{~d} 6$ ), and "that which comes to be but never is" (Timaeus $27 \mathrm{~d} 6-28 \mathrm{ar}$; omitting aei with some MSs), a description of how we grasp the members of each class, the principle that things that come to be must have a cause, the rules of craftsmanship, and the status and limitations of a speech on the selected topic. The rest of the speech unfolds in three main parts. First, Timaeus explains the products of intelligent craftsmanship (Timaeus $29 \mathrm{~d} 4-47 \mathrm{e} 2$ ). Then he gives an account of the creations of necessity (Timaeus $\left.47 \mathrm{~d}_{3}-6955\right)$. Finally, he describes how Intellect and Necessity cooperate in the creation of human beings and all other living creatures (Timaeus 69a6-92c9). Timaeus' main passages about time, cosmos, and their relation occur in the first two parts of the dialogue. The interpretation of these passages is famously difficult.

Most scholars, however, agree on the following points. Timaeus argues that the cosmos is unique, spherical, intelligent, immortal, and a beautiful living being that includes within itself all other species of living creatures. The cosmos, in addition, is the best possible image of an eternal, unchanging model. Time, in turn, is the "moving image" of the eternity of the model. The circular and regular movements of the sun, the moon, and the planets set the different

3 The Panathenaea was an Athenian religious festival in honor of Athena Polias and Erechtheus. The festival was celebrated annually and in great numbers every four years. On the connections between the festival and the contents of the Timaeus, see O'Meara 2017, chapter 2, and Nagy 2002.

4 Socrates summarizes his speech in Ti. 17b-19a.

5 Before Timaeus' speech, however, Critias summarizes the story of how ancient Athens rejected the invasion of Atlantis (Ti. 2od-26c). The end of Timaeus' speech coincides with the end of the dialogue. Plato's Critias offers an incomplete version of Critias' speech, whereas there is no record of a dialogue containing Hermocrates' speech. 
units of time, including the day and night, the months, and the years (Timaeus $37 \mathrm{e})$. Although the cosmos and everything within it are in constant change, it has everlasting regularities, proportion, geometry, and a teleological order.

In almost all other topics and details, the dialogue's interpretation has been hotly debated. Most disagreements stem from what scholars call "the status of Timaeus' speech," which refers to the extent that Timaeus' descriptions are meant to be taken at face value or not. ${ }^{6}$ In various passages, Timaeus alerts his interlocutors about the limitations of giving an account about the cosmos. From the beginning, he labels his speech a "likely story" (eikōs mythos) and later he calls it a "likely argument" (eikōs logos). In his preamble, he explains:

On the subject of an image and its model, we must make the following specification: the accounts we give of things have the same character as the subjects they set forth. So accounts of what is stable and fixed and transparent to understanding are themselves stable and unshifting. We must do our very best to make these accounts as irrefutable and invincible as any account may be. On the other hand, accounts we give of that which has been formed to be like that reality, since they are accounts of what is a likeness, are themselves likely, and stand in proportion to the previous accounts, i.e., what being is to becoming, truth is to convincingness. Don't be surprised then, Socrates, if it turns out repeatedly that we won't be able to produce accounts on a great many subjects - on gods or the coming to be of the universe- that are completely and perfectly consistent and accurate. Instead, if we can come up with accounts no less likely than any, we ought to be content, keeping in mind that both I, the speaker, and you, the judges, are only human. So we should accept the likely tale on these matters. It behooves us not to look for anything beyond this.

Timaeus $2 \mathrm{bb}_{3}-\mathrm{d}_{3}{ }^{7}$

6 There are at least two other famous debates around the Timaeus. One is about its relation to other Platonic dialogues. This debate started with Owen (1953), who challenged the widespread view that Timaeus is a late dialogue and proposed, instead, that it belongs to the middle period. Cherniss (1957), in turn, responded by defending the traditional view. The discussion was later continued by Prior (1985, 168-93), Fine (1988, 374-79), Mueller (1989 820), Ledger (1989) and Brandwood (1990, 250). The second debate concerns the extent to which the Timaeus is indebted or influenced by Pythagorean philosophy. This debate goes back to Taylor (1928), who argued that the Timaeus was a 'deliberate attempt to amalgamate Pythagorean religion and mathematics with Empedoclean biology" (p. 10) and that it was a mistake to look for distinctive Platonic doctrines in the dialogue. This view was later refuted by Cornford (1935 [1997], vi-x). However, some still find important Pythagorean aspects in Timaeus' cosmology. See McClain (1978) and Horky (2013).

7 Translated by Zeyl 2000. 
Although Timaeus' speech offers an overt description of the creation of the cosmos and time, many take the description as a non-literal tale with a deeper philosophical meaning. Others take it literally and see an attempt at offering a reasonable account of the beginning of the cosmos. Ancient authors and modern scholars alike have offered evidence and extensive arguments to justify their readings of the dialogue. Although many believe that there is a correct way to read the dialogue, the text seems to lend itself and be compatible with different readings depending on the initial assumptions and the different implications one is willing to accept. What is clear is that these controversies have always made the Timaeus Plato's most studied and influential dialogue.

Plato discusses cosmological questions in other dialogues too. In contrast with Timaeus, in Republic 7, due to the celestial bodies' corporeal nature, Socrates doubts that observational astronomy can reach any truth about their movements. The limitations of our observations, however, invite us to think beyond sense perception. For this reason, he proposes to replace traditional astronomy with "real astronomy," which he understands as the purely theoretical study of movement.

Later, in Republic 10, the myth of Er describes a column of light at the center of the cosmos, stretching over the whole of heaven and earth, and whose light binds the heavens and holds its entire revolution together. This forms the central axis of the universe, and from its extremities hangs the spindle of Necessity. The whorl of the spindle consists of different hollow whorls closely nested inside each other with their rims appearing as circles from above. The whole spindle turns at the same speed, but the inner circles revolved in an opposite direction and at different speeds. The spindle turns on the lap of Necessity, and each circle is accompanied by a siren uttering a single sound. On three equidistant thrones, the Fates, daughters of Necessity, sing to the music of the Sirens, Lachesis singing of the past, Clotho of the present, and Atropos of the future. ${ }^{8}$

In the Statesman, in turn, the main interlocutor, the Eleatic Stranger, offers a cosmological tale (Statesman $268 \mathrm{~d}-274 \mathrm{e}$ ) that explains and ties together three traditional Greek myths. ${ }^{9}$ According to this account, the cosmos as we know it

8 Resp. 10, 616b-617c.

9 One is the quarrel between Atreus and Thyestes for the throne of the Mycenaeans, in which Zeus showed his support for Atreus' claim by reversing the direction of the setting and rising of the sun and the stars. Another is the Kingship of Cronus, known as the golden age of men. The last one is the myth that earlier men were earthborn, not reproduced from each other. 
rotates on its own, but slowly and steadily becomes disharmonious. To restore its order and guarantee its immortality, God must periodically intervene and take over the rotation of the cosmos, changing its direction for an allotted period of time. The change of rotation causes great disasters and when God is guiding it people are born from the earth and grow backwards (from old to young). They live without toils and are ruled by minor divinities. ${ }^{10}$

The Statesman's cosmology shares some similarities with the one offered by Timaeus. In both cases, the cosmos is a living and intelligent being which rotates in a regular fashion. But unlike the Timaean cosmos, in the Statesman the cosmos turns on a pivot, like in the myth of Er. Moreover, in the Statesman, time does not depend on the movement of the celestial bodies, so when God changes their direction, time continues to flow in the same direction. ${ }^{11}$ Only generation reverses its course. ${ }^{12}$

In Plato's Laws $\mathrm{x}$ we also get an examination of cosmological principles. ${ }^{13}$ The topic arises from a discussion about the dangers of atheism. According to the Athenian - the main interlocutor in the dialogue - atheists argue that the celestial bodies, instead of gods, are just earth and stones, incapable of caring for human affairs (Laws 886e). One of the doctrines that defends this position attributes everything that has come to be, is coming to be now, or will come to be later either to nature, chance, or art. The doctrine maintains, however, that the celestial bodies and their movements are caused only through nature and chance without art, intelligent planning, or any deity (Laws 889a-e). Gods, in this view, are human inventions, legal fictions. The Soul, in turn, derives from the four material elements and not the other way around.

The Athenian argues that the mistake in this type of cosmology consists in misunderstanding the nature of Soul and denying its priority. His argument starts by distinguishing between self-generating motion and transmitted motion. The former moves itself and other things, whereas the latter moves other things but not itself, since it can only be moved by another motion. From this he argues that the first cause of motion has to be self-generating motion.

10 People normally read the myth as having two recurring eras (one where the cosmos is guided by God, one with the cosmos rotating on its own). Brisson (1995), however, reads the myth as having three eras, whereas Carone $(2004,2005)$ argues for five. For a recent defense of the traditional reading see Gartner and Yau (2O20).

11 Giorgini (2005, 199), however, uses Ti. 39c-d to suggest that time reverses in the Statesman. Against this idea see, for example, Statesman 272a-b and 270e9-217a1.

12 The Statesman myth, however, is closer to Critias' account at Ti. 22b-23d.

13 Plato's dialogues contain many other passages relevant for cosmology, even if they do not attempt to offer a cosmology as such. See for example Phd. 107c-115a, Phdr. 245c-246a, Phlb. 3oa-c, Soph. 248e-249d, Leg. 7, 821b-d. 
But something that moves itself, he continues, must be alive, and everything alive has a soul. The Athenian then defines the Soul as self-generating movement, which makes Soul the first source of all movement and guarantees its priority over matter. He later claims that the Soul is the cause of all things, including good and evil, beauty and ugliness, justice and injustice. In his account, the best kind of souls, rational and virtuous, control the movements of the heavens (Laws 895a-897).

The cosmology in Laws $\mathrm{x}$ reminds us of the Timaeus, but it raises some exegetical puzzles too. Although in both dialogues the soul has priority over body, souls in the Timaeus are never defined as self-generating movement. In Laws $\mathrm{x}$, the Athenian explicitly holds that souls cause all motion, whereas Timaeus is unclear about it. Some use Laws $\mathrm{x}$ to defend particular interpretations of the Timaeus, others think that they contain two different and incompatible cosmologies.

Let us now turn our attention to Plato's Parmenides. The characters in this dialogue do not offer a cosmology proper, ${ }^{14}$ but in the second part of the dialogue, Parmenides and Young Socrates examine some arguments about time, temporal relations, the now, and the instant. The general context of these arguments is the demonstration of Parmenides' method of training in philosophy. This starts with assessing the consequences of Parmenides' hypothesis that the One is (ei hen einai; Parmenides 137c4). One of the arguments deduces that if the One is, it does not come to be, nor is it older, younger, or of the same age as anything (Parmenides 140e1-141a4). But if that is so, then the One does not participate in any way in time (Parmenides 141d6-7). Given that Parmenides and Young Socrates assume at this point that there is no other way to participate in being than to participate in time, they conclude that if the One is, in no way does it participate in being, nor is it one (Parmenides 141e7-142a1). Given that this conclusion sounds unacceptable, they start over and reconsider the hypothesis that the One is by assuming it to mean that the One participates in being (Parmenides 142a6-c7). Under this new reading of the hypothesis, the One participates in time and holds temporal relations with itself and other things (Parmenides $151 \mathrm{e}^{-152 a 3}$ ). This implies that the One advances in time, which leads Parmenides to discuss how the One relates to the "before" (to pote), "after" (to epeita), and the "now" (to nyn), and again whether it is older, younger, or the same age as itself and others (Parmenides $152 \mathrm{~b} 2-155 \mathrm{~d} 4)$.

14 However, see, for example, Wersinger Taylor 2019 and Gardner 2019. 
Shortly after this, Parmenides raises a question about when the transition from rest to moving occurs. Parmenides claims that it cannot occur at one time and introduces the notion of the instant of change:

'And whenever, being in motion, it comes to a rest, and whenever, being at rest, it changes to moving, it must itself, presumably, be in no time at all.'-'How is that?' - It won't be able to undergo being previously at rest and later in motion or being previously in motion and later at rest without changing.'- 'Obviously not.'- 'Yet there is no time in which something can, simultaneously, be neither in motion nor at rest.'-'Yes, you're quite right.'- 'Yet surely it also doesn't change without changing.'-'Hardly.''So when does it change? For it does not change while it is at rest or in motion, or while it is in time.'- 'Yes, you're quite right.'

'Is there, then, this queer thing in which it might be, just when it changes?'- 'What queer thing?'- 'The instant. The instant seems to signify something such that changing occurs from it to each of two states. For a thing doesn't change from rest while rest continues, or from motion while motion continues. Rather, this queer creature, the instant, lurks between motion and rest - being in no time at all - and to it and from it the moving thing changes to resting and the resting thing changes to moving.'- 'It looks that way.'

Parmenides $156 \mathrm{c1}-\mathrm{e} 7^{15}$

While the "now" is in time, between the "before" and "after," the instant is in no time at all, but lies between motion and rest.

Like the passages in Laws $\mathrm{x}$, the arguments in the Parmenides raise difficult exegetical questions. At first sight, the notion of time in the Parmenides seems independent from that in the Timaeus. Parmenides never mentions the movements of the celestial bodies or the creation of time by the Demiurge. But one may still think that the claims in both dialogues are compatible.

Given that Plato wrote such sophisticated texts and that the connections between them are difficult to interpret, it should come as no surprise that from the beginning, the reception of Plato's thought was subject to intense debate.

Translated by Gill and Ryan 1996. 
His readers developed contrasting exegetical strategies and, as a result, assessed his arguments and methods differently, agreeing and disagreeing with different parts of it. Here I shall only offer a brief, panoramic view of the Platonic tradition in the ancient world. This tradition, broadly understood, includes Plato's successors in the Academy, Aristotle and his followers in the Lyceum, and many later Platonic schools and philosophers, including the Stoics. ${ }^{16}$

After Plato's death in 347 BCE, his nephew Speusippus (c. 407-399 ВCE) became the head of the Academy until his death, when he was succeeded by Xenocrates (c. 396-314 вСе). ${ }^{17}$ Then Polemo (c. 350-267 вСЕ) became the third head of the Academy after Plato. Other important members of the school included Eudoxos of Cnidos (c. 390-337 BCE), Philippus of Opus, Heraclides Ponticus (с. 390-310 вСЕ), Crantor (died 276 вСЕ), and Crates of Athens (died c. 268-264 вCE). This period is known as the "Old Academy."18 It coincides with Aristotle's foundation of the Lyceum (334 BCE) and the first generations of Peripatetics. But Polemo taught Zeno of Citium (c. 334-262 BCE), who later became the founder of the Stoics. Philosophers in these three schools were careful readers of Plato. They all criticized, rejected, or developed some of Plato's arguments and ideas. ${ }^{19}$

Speusippus and Xenocrates both rejected Forms but proposed two metaphysical principles, one of unity, the other of multiplicity. They both believed that the processes described in the Timaeus were timeless and eternal, and that the creation of the cosmos was not meant literally. Most other members of the Academy agreed with this interpretation. Philippus of Opus rejected supramundane realities and divided the cosmos into five zones, each composed mainly of one element but with admixtures of all the others in small quantities. Polemo, in turn, is known for maintaining that the supreme God is immanent and can be identified with the cosmos. ${ }^{20}$

Aristotle interprets Plato differently. He reads the creation tale literally and accuses Plato of proposing a temporal beginning of the cosmos. One of the problems he finds in Timaeus is that "the heaven, though it was generated, will none the less exist for the rest of time."21 But for Aristotle, this is impossible.

16 Plato also influenced the Epicureans. See Goodman and Aikin 2017.

17 Most of the works from this period have been lost, with the exception of a couple of dialogues like Epinomis, normally ascribed to Plato's secretary Philippus of Opus, and Minos and Hipparchus, probably by an unknown author from the middle of the fourth century.

18 On this period see Dillon 2003.

19 On Aristotle's reception of Plato, see Cherniss 1944. For Plato's reception in Hellenistic philosophy, see Barnes 1991.

20 See Dillon $(1996,166)$.

21 Arist. Cael. I 10, 280a3o-32. Transl. Stocks 2014. 
In De Caelo I 12, he argues both that it is impossible for what is generated to be indestructible, or for that which is ungenerated to be destroyed. Thus, he maintains that the cosmos is ungenerated, eternal, and incorruptible. ${ }^{22}$

For Aristotle, there are five elements: earth, water, air, fire, and aether. Each of these elements has a natural place, which they will occupy if they are not hindered. This divides the cosmos into five concentric strata. The first four constitute the sublunar world; the last one is surrounded by a stratum of aether, which is ungenerated, indestructible, and constitutes the heavens. The movements of the celestial motions are explained by a system of concentric spheres, which are ultimately moved by the Prime Unmoved Mover. The cosmos is not infinitely large, but outside of it there is no void, place, or time. ${ }^{23}$ That there is no time outside of the cosmos is clear if one considers Aristotle's definition of time as "a number of change with respect to the before and after." ${ }^{4}$ Since there is no change outside the cosmos, there cannot be time either. Theophrastus (c. 371-287 BCE), Aristotle's successor as head of the Lyceum, deserves a brief mention. He seems to have questioned Aristotle's division of the cosmos. Instead, he conceived the cosmos as a continuous, single, and complete living organism. Moreover, it seems that he located the cause of movement of the heavens in the heavens themselves, rather than in their desire for a Prime Mover or something else. He conceived time as an accidental attribute of motion. ${ }^{25}$

The Stoics defended various accounts according to which the cosmos generates, develops, is burned up by a conflagration, and even generates again in an endless cycle. Although these accounts share their fundamental tenets, they also reveal an ongoing engagement with the previous philosophical tradition, with other contemporary schools of thought and a debate inside the Stoa. It is possible to understand their cosmologies as a critical continuation of complex philosophical debates started by Heraclitus, Anaximenes, the Pythagoreans, Plato, and the Old Academy. ${ }^{26}$

Like Plato, the Stoics presuppose a single-cosmos order. They propose two first principles of this cosmos, which cannot be reduced to one another. Both principles are bodies that occupy space and offer resistance; they are

22 Arist. Cael. I 10-12; II 13. Aristotle's arguments in Cael. I 12 where very influential and may have motivated some Academic philosophers to take a non-literal reading of Timaeus.

23 Arist. Cael. I 9, 279a11-ff.

24 Arist. Ph. 4, 11, 219b 1-2.

25 See Ierodiakonou 2020.

26 See, especially, DK22B $30-31, \mathrm{DK}_{13} \mathrm{~A}_{5}-7$, DK58B34, Plato's Phaedo, Theaetetus, Philebus, Sophist, and Timaeus, Cicero's Academica I 24-29; whether they had access to Aristotle's texts and later Peripatetic philosophy is a more controversial issue. 
ungenerated, indestructible, and inseparable. One is described as that which acts and the other as that which is acted upon. The Stoics identified the first one with "God," "reason," or "cause," and the second one with the "unqualified substance," "matter," or "substrate." ${ }^{27}$ According to their accounts, God pervades the entirety of matter through and through, and structures it according to its perfect, inescapable, and intelligent designing plan, to create the cosmos, its current state, and, even its endless cycle of conflagration and regeneration. ${ }^{28}$ The Stoics understood God's relation to matter as that of a soul to its body. Consequently, they thought of the cosmos as a divine living organism. ${ }^{29}$ For the Stoics, time is incorporeal and infinite on either side. ${ }^{30}$ Zeno defined it as "the dimension of all motion without qualification,"31 and later Chrysippus conceived of it as "the dimension of the world's motion according to which the measure of speed and slowness is spoken of; or the dimension accompanying the world's motion." 32

After Polemo the Academy turned to skepticism and an aporetic interpretation of Plato's dialogues. This period, known as the New or Skeptical Academy, begins with Arcesilaus $\left(316 / 5^{-241 / 0 ~ в С E), ~ a n d ~ i n c l u d e s ~ L a c y d e s, ~}\right.$ Telectles, Evander, Hegesinus, Carneades (214/3-129/8 все), Hagnon of Tarsus, Clitomachus (187/6-110/9 BCE), and Philo of Larissa (159/8-84/3 вCE). Many of the members of the Academy engaged in polemics with the Stoics, whom they saw as dogmatic. ${ }^{33}$ Philo of Larissa taught for some years in Rome, and Cicero (106-43 BCE) became his student. He was also the last undisputed scholarch of the Academy, and after his death in $84 / 3$ BCE the school split into various factions.

Scholars refer to the next stage as Middle Platonism. ${ }^{34}$ It usually starts with Antiochus of Ascalon (c. 125-68 ВСE), one of Philo of Larissa's students in Athens. Antiochus distanced himself from the skeptical interpretation of Plato and took inspiration from the Old Academy, Aristotle, and the Stoics. Antiochus' cosmology was a combination of Platonic and Stoic doctrine. He

27 See DL 7.134=LS44B; Sextus Empiricus, Math. 9.75-76=LS44C; Calcidius, In Tim. 292= LS44D; Calcidius, In Tim. 293=LS44E; Seneca, Letters 65.2=LS55E.

28 See Euseb. Praep. evang. 15.14.2=LS46G; Calcidius, In Tim. 144=LS54U.

29 Plutarch, $s R{ }_{1053} \mathrm{~B}=\mathrm{LS} 46 \mathrm{~F}$; Origen, C. Cels. 4.14=LS46H; Euseb. Praep. evang. 15.15.1-9= LS67L.

3 Sextus Empiricus Math. 10.218=LS27D; Stobaeus 1.106,5-23=LS51B.

31 Simpl., In Cat. $35^{\circ}, 15^{-16}=\mathrm{LS}_{51} \mathrm{~A}$.

32 Stobaeus 1.106,5-23=LS51B.

33 On this period see Schofield, Burnyeat, and Barnes 1980.

34 For this period see Dillon 1996, Boys-Stones (2001; 2017), the first four chapters of Karamanolis 2006 and Schofield 2010. 
maintained that the universe was governed by a providential, immanent God, and that his providence consisted in the activity of his reason, which was the law of nature and the Soul of the world. For him, nothing was better than reason, the common possession of humans and gods. ${ }^{35}$

Several schools and important philosophers emerged during the next couple of centuries. Alexandria became an important center for Platonic and Neopythagorean philosophy with Eudoros (first century BCE) and Philo of Alexandria (c. $20 \mathrm{BCE}-5 \mathrm{O} \mathrm{CE}$ ). The latter taught Ammonius of Athens (first century CE), who in turn taught Plutarch of Chaeronea (c. 45-120 CE). Athens remained an important place for philosophy too, with the contributions of Nicostratus, Calvenus Taurus (second century CE), Atticus (fl. c. $175 \mathrm{CE}$ ), Harpocration of Argos, and Severus. There was also a Neopythagorean movement that incorporated Plato into their philosophy. One of its members was Numenius of Apamea (fl. late second century CE). We also find "the school of Gaius" around the second century CE. In addition, the Gnostic and Hermetic writings, as well as the Chaldean Oracles, were heavily influenced by Platonism and later used by Neoplatonic philosophers. Other important philosophers from this period include Theon of Smyrna (fl. 10o CE), Maximus of Tyre (fl. late second century CE), Alcinous (second century CE), Celsus (second century $\mathrm{CE}$ ), and Calcidius, as well as the Christian Platonists, including Clement of Alexandria (c.150-215 CE) and Origen (c.184-253 CE).

It is impossible to do justice to all these thinkers here, but let it suffice to say that the period saw a revival of theories of transcendent first principles. Many philosophers in this period accepted the non-literal interpretation of the Timaeus and maintained that the cosmos was eternal and ungenerated. However, Plutarch and Atticus defended a literal interpretation of the Timaeus and maintained that the cosmos was created by God.

The last stage I will mention is commonly known as Neoplatonism. ${ }^{36}$ The first and most famous philosopher of this period was Plotinus (205-27O CE), who was taught by Ammonius Saccas (fl. third century CE). Plotinus divided reality into two categorically different realms, the sensible and the intelligible. The latter is divided in turn into three levels, called hypostases. On top we find the first cause of everything else. This is an ineffable principle, known as the One or the Good. The second level derives timelessly from the One, and is the Intellect, which contains all the Forms. From the Intellect derives in turn the Soul, which creates the sensible universe at the same time as it creates time. For Plotinus, this meant that

35 Attributing the views in Cicero, De Legibus I 23 to Antiochus. See Dillon (1996, 80).

36 The division is however artificial, and the label is an invention from early nineteenth-century scholarship. 
the cosmos as a whole, the heavens, and the celestial bodies were everlasting, and time was the life of the Soul. ${ }^{37}$ As in Plato's Timaeus, the sensible realm is an imperfect image of the intelligible. The sensible cosmos is a living, intelligent organism that contains all other organisms, material instantiations of the Forms, and matter.

Later Neoplatonists included Porphyry (c. 234-305 CE), Iamblichus (c. 242$325 \mathrm{CE}$ ), Syrianus (died c. $437 \mathrm{CE}$ ), Proclus (412-485 CE), Marinus (born c. 440 CE), Damascius (C. $45^{8-538 ~ C E}$ ), and Simplicius (c. 490-56o CE), as well as the Christian theologians John Philoponus (c. 490-570 CE), and Pseudo-Dionysius the Areopagite (late fifth to early sixth century $\mathrm{CE}$ ). It would be impossible to summarize their philosophical contributions here, but in short, they developed sophisticated metaphysical systems and wrote insightful commentaries on Plato and Aristotle. Like Plotinus, they defended the everlastingness of the cosmos and an absolute conception of time, in which time was independent and prior to things in time. ${ }^{38}$

\section{Motivation and Overall Structure of the Volume}

Within this larger context, the present volume makes a non-exhaustive and humble contribution to our understanding of Plato and some parts of the Platonic tradition. The motivations that led to this volume were threefold. Firstly, in Platonic scholarship, we wanted to restart and move the discussion forward regarding Plato's conception of time in the context of his cosmology. In a way, Plato's conception of time and the cosmos has been discussed at length. ${ }^{39}$ However, on the specific topic of time and its relation to the cosmos, most recent authors have simply aligned themselves to previous interpretations, repeating known arguments or textual observations. The few attempts to break with these traditional readings of Plato ${ }^{40}$ have raised important

37 On Plotinus' cosmology, see Enneads II-III. See also Wilberding 2006 and Chase 2014.

38 See for example Proclus, Elem. Theol. § 5 2-3.

39 See, for example, Cornford (1935) 1997, Owen 1936; 1966, Vlastos 1939; 1964, Callahan 1948, Philippson 1949, Fränkel 1955, Hackforth 1959, Leyden 1964, Brague 1982, Sorabji 1983, Mohr 1985, Baltes 1996, Dillon 1997, and Keizer 20oo. The last twenty years have greatly advanced our understanding of Plato's cosmology and metaphysics. See, for example, Natali and Maso 2003, Johansen 2004, Karfik 2004, Carone 2005, Leinkauf and Steel 2005, Gregory 2007, Sedley 2007, Mohr and Sattler 2010, Fronterotta 2010, and Broadie 2012. Although they appeared too late for the present volume to take proper account of them, see also Sattler 2020, and Jorgenson, Karfík, and Špinka 2020.

For example by Carone 2005, Johansen 2004, and Fronterotta 2010. 
questions and motivated renewed interest in Plato's cosmology and understanding of time. The chapters of this volume dedicated to Plato aim to contribute to this growing interest, and to the new wave of interpretations and textual observations regarding Plato's philosophy of time and cosmology.

Secondly, we wanted to explore Plato's influence on Peripatetic and Stoic philosophy, understood here as two rightful branches of the Platonic tradition. Although most scholars agree that the Peripatetics and Stoics were careful readers of Plato, sometimes it is assumed that only the Old Academics, Middle Platonists, and Neoplatonic philosophers count as true heirs of Plato. In this volume, we actively challenge this assumption and believe that in doing so, we can modify how scholars perceive Plato's role and importance for the history of cosmology. We also wanted to reconnect contemporary Platonic scholarship with debates in the ancient Platonic tradition.

A third and more general motivation was the need for a better and up-todate understanding of Plato's contribution to the philosophy and history of physics, especially regarding time and the models and metaphors of the beginning of the universe. In many historical surveys of physics and cosmology, Plato receives only a brief and sometimes superficial mention. ${ }^{41}$ Authors often use Plato to introduce Aristotle, who is taken to be the first systematic thinker deserving of detailed analysis. Moreover, to date, there has been no recent volume dedicated to Plato's notion of time and its relation to cosmology. Despite this tendency to omit Plato, the Timaeus and the Parmenides were two of the most influential texts in antiquity, and, although this exceeds the scope of the present volume, they were also fundamental texts for medieval and early modern philosophers and cosmologists. This volume aims to bolster what little attention Plato's contribution has received in the history of science and the philosophy of physics. We believe Plato had an impact that is detectable across centuries, up to today, and deserves a central role in the history of ancient cosmology and a whole chapter in introductions to philosophy of time.

Given the shared aims, overlap of topics, and interconnections, the volume offers its eight chapters in a continuous order. The reader will find, however, that the first six chapters are mainly dedicated to interpreting Plato, whereas the last two discuss his reception by Aristotle and the Stoics. While chapter

41 For example, Bardon (2013) dedicates sections to Parmenides and Zeno of Elea but then omits Plato and jumps straight to Aristotle and Augustine. Similarly, in the volume edited by Dyke and Bardon (2013), part I puts together a section dedicated to the history of philosophy of time that includes excellent chapters on Heraclitus and Parmenides, Zeno's Paradoxes, Aristotle, and the Stoics. However, it completely ignores Plato and Neoplatonism. 
one is exclusively dedicated to Plato's Statesman, chapters two to six offer contrasting exegetical approaches to the Timaeus (most of them also include discussion and comparisons with the Laws, Parmenides, and other dialogues). Thematically, four chapters (chapters one, four to six) explore different aspects of Plato's conception of time, including its creation (chapter four), its relation to human nature (chapter one), light (chapter five), and instantaneity (chapter six). The other four chapters (chapters two, three, seven, eight) focus instead on God's relation to the cosmos, including the Demiurge's status and role (chapters two and three) and the discussion of the intelligence and source of movement of the cosmos (chapters seven and eight). That being said, to some extent most of the chapters discuss both topics. The chapters also offer various methods and approaches, representing different traditions of interpreting and analysing Plato and his successors. In what follows, I offer a brief summary of each chapter.

\section{Summary of the Contents}

Chapter one offers an innovative approach to the cosmological myth in Plato's Statesman by focusing on the continuity between the cosmic ages in the myth and the persistence of humanity over time. Chapters two and three discuss the role of the Demiurge in Plato's cosmology and argue for opposing theses. One argues that the Demiurge is a separate intellect with an efficient and goal-directed, causal role. The other rejects that the Demiurge is a separate intellect and argues instead that the description of demiurgic activity is a thought experiment that helps us visualize the cosmos' participation in the intelligible model. The next pair of chapters offer close, literal readings of time in the Timaeus. Chapter four discusses the creation of time and the precosmos, whereas chapter five analyzes Timaeus' theory of light to understand his definition of time. Chapter six analyses the notion of the "instant" in the Parmenides and uses it to interpret the Timaeus. The last two chapters explore the reception of Plato's cosmology. Chapter seven reads Aristotle's arguments in Physics ViII.5 as a criticism of Plato's Laws X and Timaeus. The final chapter distinguishes three families of arguments for the intelligence of the cosmos and tracks their Platonic background in passages from the Timaeus and Philebus. In what follows, I summarize the main argument of each chapter.

Jenny Bryan writes chapter one, entitled "Continuity and Community in the Myth of the Statesman." The chapter argues that although the Stranger's myth contrasts the Ages of Kronos and Zeus and the communities living in each epoch, it also stresses the continuity between both communities. This 
expands the sense of "us" to refer to a community of humans that persists through the Ages. The myth, Bryan argues, does not talk about different races of human beings but different epochs of the history of humanity. But the myth also reminds us that these Ages are all part of a divine design. During one of the Ages, God let go of his creation, but this is never a total abandonment. The myth is thus designed to make us recognize not only our place in a divinely designed cosmos but also the times we live in, and our broader place in the history of humanity.

In chapter two, "The Demiurge and His Place in Plato's Metaphysical Scheme," Viktor Ilievski argues that, for Plato, the Demiurge should not be dismissed as a didactive device or, as many believe, identified with the World Soul. Instead, the chapter argues that the Demiurge personalizes an independent nous, which is a separate, new entity that represents a creative and governing cosmological principle. In this way, Ilievski gives the Demiurge a central role in Plato's cosmology and late metaphysics, making it the supreme God and highest causal principle.

The chapter is divided into three sections. The first two offer a concise and useful history of the discussion both in ancient and contemporary authors. These sections map the vast history of interpretation of the Demiurge's role in Plato's metaphysics, and then focus on some of the authors who aid the chapter's thesis, including Plutarch, Atticus, and Proclus in the ancient world, as well as modern scholars like Hackforth, Mohr, Menn, Brisson, Johansen, and Broadie. Ilievski argues that a careful look at the development of Plato's interpretations shows that the discussions culminate in recognizing the Demiurge is a separate nous, distinct both from the World Soul and the Good. In the last section, he goes back to Plato and analyzes the main passages from the Timaeus and other dialogues like the Laws, Philebus, and Statesman. He then argues that the Demiurge has a causal role that is both efficient and goal-directed.

Luca Pitteloud defends a different interpretation of the Demiurge's role. In chapter three, "Goodbye to the Demiurge? Timaeus' Discourse as a Thought Experiment," he argues that the Demiurge should not be understood as a cosmological or ontological principle, but rather as an epistemological point of view. Pitteloud argues for the best explanation. He proposes to understand the eikōs mythos as a thought experiment whose aim is to place the reader inside the mind of the Demiurge. In this way, as readers of Plato, we re-enact in our minds the constitution of the cosmos and, by doing so, we can obtain new information and a better understanding of the universe. For Pitteloud, this reading of Timaeus' speech makes sense of passages where we find detailed accounts of the reasoning and decision making of the Demiurge. Moreover, the thought experiment allows the reader to visualize the cosmos from two 
different perspectives, the external standpoint of the Demiurge and the internal, and human, viewpoint. But if that is the main purpose of the creation story and the Demiurge's role, one might wonder whether it would not be more reasonable to say goodbye to the Demiurge as a separate intellect. Pitteloud offers a clear interpretation that, although briefly considered by Johansen, Brisson, and Burnyeat, receives here a detailed and sophisticated defense for the first time.

In chapter four, "Before the Creation of Time in Plato's Timaeus," I defend, against its more recent critics, a literal, factual, and consistent interpretation of Timaeus' creation of the cosmos and time. My main purpose is to clarify the assumptions under which a literal interpretation of Timaeus' cosmology becomes philosophically attractive. I propose five exegetical principles that guide my interpretation. Unlike previous literalists, I argue that assuming a "pre-cosmic time" is a mistake. Instead, I challenge the exegetical assumptions scholars impose on the text and argue that for Timaeus, a mere succession of events and the relations derived from it (before, after, simultaneous with) imply no time, given the narrow definition of the term used in the dialogue. For Timaeus, I explain, time is measurable, regular, and dependent on the motion of the celestial bodies. A mere succession of events like the one needed to understand the creation story and the pre-cosmos requires none of these elements. Readers of Plato erroneously assume that a succession of events implies time, but that is to impose a conception of time absent in the text. The chapter offers a detailed reconstruction of the pre-cosmic stage under a literalist interpretation and argues how it is compatible with the immutable relationship between the Demiurge and the cosmos.

The next chapter tackles more directly the question about the nature and definition of time in the Timaeus. It is entitled "Time and Light in Plato's Timaeus," and in it, Carolina Araújo analyzes Timaeus' theory of visibility and light to better understand the conception of time at play in his cosmological discourse. Araújo starts by arguing that, for Timaeus, the cosmos is generated because it is visible and not, as it is often assumed, the other way around. According to Timaeus, she continues, visibility is possible thanks to the moving body of light streaming from the sun, which connects the particles of light in objects with those in our eyes. But this theory, Araújo notices, fails to explain night vision. This is an important flaw in the theory given that astronomical observations are essential for a proper understanding of the cosmos and its role as an image of the eternal model. Araújo explains the concept of cosmic days and nights as distinct temporal units and argues that Timaeus aims to build a calendar based on these units. This implies overcoming the challenge of calculating the motion of all celestial bodies in relation to the sun. In the last 
part of the chapter, Araújo uses these results to interpret Timaeus' account of time and to argue that time is the movement of all heavenly bodies relative to the motion of light streaming from the sun.

Chapter six, "Eternity, Instantaneity, and Temporality: Tackling the Problem of Time in Plato's Cosmology" by Silvia De Bianchi, explores the relation between change, time, and atemporality in late Plato. De Bianchi uses the notion of instantaneity in the Parmenides to solve the puzzle of atemporality and demiurgic agency in the Timaeus. The chapter starts by showing that Plato's late dialogues deploy a rich and complex conception of atemporality, sometimes showing more nuance than contemporary accounts. De Bianchi analyzes some of the most pressing puzzles derived from Timaeus' cosmology, namely, the generation of time and the transient character of the receptacle. She proposes to solve these puzzles by considering the notion of the instant in Parmenides, which she understands as a distinct type of atemporality.

In his chapter, "Is the Prime Mover a Soul? A Critique of a Platonic Thesis in Physics VIII," Alberto Ross reconstructs Aristotle's criticisms against the idea that the Prime Mover is a soul in Physics viII. Aristotle argues that the Prime Mover must be immaterial and absolutely immobile in order to explain the continuity and the eternity of change. This means that it must not undergo any movement at all, not even of an accidental form. But this implies that the Prime Mover should be different from other kinds of principles of motion, such as souls, which are immobile movers, but which undergo accidental motion. Ross proposes to read Aristotle's clarification of this point as a reaction against the positions defended by Plato in Laws $\mathrm{x}$ and the Timaeus, according to which the cosmos is an animal composed of body and soul, and to argue that this soul is a kind of first principle for nature and change.

The last chapter is dedicated to Stoic cosmology and its Platonic heritage, and is entitled "Stoic Cosmic Intelligence and its Platonic Background." In this chapter, Ricardo Salles classifies surviving Stoic texts into three families of Stoic proofs for the intelligence of the cosmos. Then he analyzes them and tracks the arguments' antecedents in Plato. The first family goes back to the Timaeus. The argument rests on the teleological thesis that the role of human intelligence is to contemplate the cosmos. This family of proofs differs from the other two because the latter argue from a different starting point. Families two and three argue for the intelligence of the cosmos from an account of the origins of human intelligence. Salles shows that these two families have striking parallels with proofs for the intelligence of the cosmos in Plato's Philebus and Xenophon. But these two families, Salles explains, also differ in the way they conceive the origins and transmission of human intelligence. This difference 
makes Salles conclude that the third family is more strongly connected to the proof found in Philebus and Xenophon. ${ }^{42}$

\section{References}

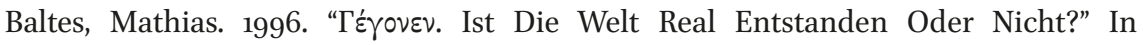
Polyhistor: Studies in the History and Historiography of Ancient Philosophy, edited by Keimpe A. Algra, Pieter W. van der Horst, and David T. Runia, 76-96. Leiden: Brill.

Bardon, Adrian. 2013. A Brief History of Philosophy of Time. New York: Oxford University Press.

Barnes, Jonathan. 1991. “The Hellenistic Platos." Apeiron 24, no. 2: 115-28.

Boys-Stones, George. 2001. Post-Hellenistic Philosophy A Study of Its Development from the Stoics to Origen. New York: Oxford University Press.

Boys-Stones, George. 2017. Platonist Philosophy 80 BC to AD 250. Platonist Philosophy 80 $B C$ to $A D$ 250. Cambridge University Press.

Brague, Rémi. 1982. Du Temps Chez Platon et Aristote: Quatre Études. Paris: Presses Universitaires de France.

Brandwood, Leonard. 1990, The Chronology of Plato's Dialogues. Cambridge: Cambridge University Press.

Brisson, Luc. 1995. "Interprétation Du Mythe Du Politique." In Reading the Statesman, edited by Christopher Rowe, 349-63. Sankt Augustin: Academia Verlag.

Broadie, Sarah. 2012. Nature and Divinity in Plato's Timaeus. Cambridge: Cambridge University Press.

Callahan,John F.1948. Four Views of Time in AncientPhilosophy. Harvard University Press.

Carone, Gabriela Roxana. 2004. "Creation in the Timaeus: The Middle Way." Apeiron 37, no. 3: 211-26.

Carone, Gabriela Roxana. 2005. Plato's Cosmology and Its Ethical Dimensions. New York: Cambridge University Press.

Chase, Michael. 2014. "Time and Eternity from Plotinus and Boethius to Einstein." Schole 8, no. 1: 67-110.

Cherniss, Harold F. 1944. Aristotle's Criticism of Plato and the Academy. 2 vols. Baltimore: Johns Hopkins University Press.

42 I am grateful to Viktor Ilievski, Alberto Ross, Silvia de Bianchi and the anonymous reviewers for Brill's Plato Studies Series for their feedback on previous versions of this introduction. This research is part of PROTEus "Paradoxes and Metaphors of Time in Early Universe(s)", a project that has received funding from the European Research Council (ERC) under the Horizon 2020 research and innovation programme (Grant agreement No. 758145$)$. 
Cherniss, Harold F. 1957. "The Relation of the Timaeus to Plato's Later Dialogues." The American Jounal of Philology 78, no. 3: 225-266.

Cornford, Francis M. (1935) 1997. Plato's Cosmology: The Timaeus of Plato. London: Routledge. Reprint, Indianapolis: Hackett.

Dillon, John. 1996. The Middle Platonism. Revised ed. London: Duckworth.

Dillon, John. 1997. "The Riddle of the Timaeus: Is Plato Sowing Clues?" In Studies in Plato and the Platonic Tradition, edited by Mark Joyal. Aldershot: Ashgate.

Dillon, John. 2003. The Heirs of Plato. A Study of the Old Academy (347-274 BC). New York: Oxford University Press.

Dyke, Heather, and Adrian Bardon, eds. 2013. A Companion to the Philosophy of Time. Chichester: Wiley Blackwell.

Fine, Gail (1988). "Owen's Progress: Logic, Science, and Dialectic: Collected Papers in Greek Philosophy." Philosophical Review 97, no. 3: 373-399.

Fränkel, Hermann. 1955. "Die Zeitauffassung in Der Frühgriechischen Literatur." In Wege Und Formen Frühgriechischen Denkens, edited by F. Tietze, 1-22. Munich: Beck.

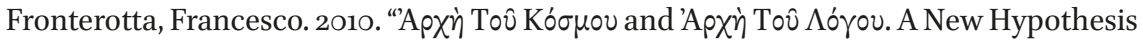
on the Beginning of the World in Plato's Timaeus." In Philosophy and Dialogue. Studies on Plato's Dialogues, edited by A. Bosch-Veciana and J. Monserrat-Molas, 141-55. Barcelona: Barcelones.

Gardner, Darren. 2019. "Plato's Parmenides and the Knowable Many: Cosmos as Discursive Order in Hypothesis 3." Études Platoniciennes [Online] 15. Accessed December 14, 2020. https://doi.org/https://doi.org/10.400o/etudesplatonicien nes.1626.

Gartner, Corinne, and Claudia Yau. 2020. "The Myth of Cronus in Plato's Statesman: Cosmic Rotation and Earthly Correspondence." Apeiron 53, no. 4: 437-62. Gill, M. L., and P. Ryan. 1996. Plato: Parmenides. Indianapolis: Hackett.

Giorgini, Giovanni. 2005. Platone: Politico (Ed. Critica). Milan: BUR.

Goodman, Lenn E., and Scott Aikin. 2017. "What Did Epicurus Learn from Plato?" Philosophy 92, no. 3: 421-447.

Gregory, Andrew. 2007. Ancient Greek Cosmology. Bristol: Bristol Classical Press.

Hackforth, R. 1959. "Plato's Cosmogony (Timaeus 27 d Ff.)." The Classical Quarterly 9, no. 1: 17-22.

Horky, Philip S. 2013. Plato and Pythagoreanism. New York: Oxford University Press. Ierodiakonou, Katerina. 2020. “Theophrastus.” The Stanford Encyclopedia of Philosophy (Winter 2020 Edition). Stanford University. Accessed December 14, 2020. https:// plato.stanford.edu/archives/win2020/entries/theophrastus/.

Johansen, Thomas Kjeller. 2004. Plato's Natural Philosophy. Cambridge: Cambridge University Press.

Jorgenson, C., Karfík, F., \& Špinka, Š. 202O. Plato’s Timaeus. Plato’s Timaeus. Leiden \& Boston: Brill. https://doi.org/10.1163/9789004437081. 
Karamanolis, George E. 2006. Plato and Aristotle in Agreement? Platonists on Aristotle from Antiochus to Porphyry. New York: Oxford University Press.

Karfik, Filip. 2004. Die Beseelung Des Kosmos: Untersuchungen Zur Kosmologie, Seelenlehre Und Theologie in Platons Phaidon Und Timaios. Munich and Leipzig: K. G. Saur Verlag.

Keizer, Heleen M. 200o. "Eternity' Revisited: A Study of the Greek Word AISN'." Philosophia Reformata 65, no. 1: 53-71.

Ledger, G. R. 1989. Re-counting Plato: A Computer Analysis of Plato's Style, Oxford: Clarendon Press.

Leinkauf, Thomas, and Carlos Steel, eds. 2005. Platons Timaios Als Grundtext Der Kosmologie in Spätantike, Mittelalter Und Renaissance. Leuven: Leuven University Press.

Leyden, W. von. 1964. "Time, Number, and Eternity in Plato and Aristotle." The Philosophical Quarterly 14, no. 54: 35-52.

McClain, Ernest G. 1978. The Pythagorean Plato. Maine: Nicolas-Hays.

Mohr, R. D. 2010. One Book, The Whole Universe: Plato's Timaeus Today. Edited by Richard D. Mohr and Barbara M. Sattler. Las Vegas: Parmenides Publishing.

Mohr, Richard D. 1985. The Platonic Cosmology. Leiden: Brill.

Mueller, Ian. 1989. “Joan Kung's Reading of Plato's Timaeus” Apeiron 22, no. 4: 1-28.

Nagy, Gregory. 2002. Plato's Rhapsody and Homer's Music: The Poetics of the Panathenaic Festival in Classical Athens. Washington, DC: Center for Hellenic Studies.

Nails, Debra. 1998. "The Dramatic Date of Plato's Republic.” The Classical Journal 93, no. 4:383-96.

Natali, Carlo, and Stefano Maso, eds. 2003. Plato Physicus: Cosmologia e Antropologia Nel Timeo. Amsterdam: A. M. Hakkert.

O'Meara, Dominic J. 2017. Cosmology and Politics in Plato's Later Works. Cambridge: Cambridge University Press.

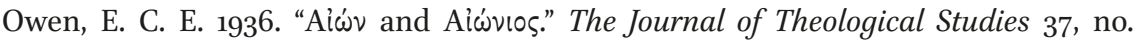
147: $265^{-83}$.

Owen, G. E. L. 1953. “The Place of Timaeus in Plato's Dialogues.” The Classical Quarterly 47: 79-95.

Owen, G. E. L. 1966. "Plato and Parmenides on the Timeless Present." Monist 50, no. 50: $317-40$.

Philippson, Paula. 1949. "Il Concetto Greco Di Tempo Nelle Parole Aion, Chronos, Kairos, Eniautos." Rivista Di Storia Della Filosofia 4, no. 2: 81-97.

Prior, W. J. 1985. Unity and Development in Plato's Metaphysics. London \& Sydney: Croom Helm.

Sattler, B. M. (2020). The Concept of Motion in Ancient Greek Thought. Cambridge: Cambridge University Press. 
Schofield, Malcolm. 2010. Aristotle, Plato and Pythagoreanism in the First Century BC: New Directions for Philosophy. Cambridge: Cambridge University Press.

Schofield, Malcolm, Myles Burnyeat, and Jonathan Barnes, eds. 1980. Doubt and Dogmatism: Studies in Hellenistic Epistemology. Philosophy. Vol. 56. Oxford: Oxford University Press.

Sedley, David. 2007. Creationism and Its Critics in Antiquity. Berkeley: University of California Press.

Sorabji, Richard. 1983. Time, Creation and the Continuum. London: Duckworth.

Stocks, J. L. 2014. “On the Heavens.” In Complete Works of Aristotle, Vol. 1, edited by Jonathan Barnes, 447-511. Princeton: Princeton University Press.

Taylor, A. E. 1928. A commentary on Plato's Timaeus. Oxford: Clarendon Press.

Vlastos, Gregory. 1939. "The Disorderly Motion in the Timaios.” The Classical Quarterly 33, no. 2: 71-83.

Vlastos, Gregory. 1964. “Creation in the Timaeus: Is It a Fiction?” In Studies in Plato's Metaphysics, edited by R. E. Allen, 401-19. London: Routledge.

Wersinger Taylor, Gabrièle. 2019. "Le Parménide de Platon: Une Cosmologie sans Kosmos?" Études Platoniciennes [Online] 15. Accessed December 14, 202O. https:// doi.org/https://doi.org/10.400o/etudesplatoniciennes.1535.

Wilberding, James. 20o6. Plotinus' Cosmology. Oxford: Oxford University Press.

Zeyl, Donald J., ed. 20oo. Plato: Timaeus. Indianapolis: Hackett. 